\title{
Improving Students' Combinatorial Thinking Ability through Numbereds Head Together
}

\author{
Rustam E. Simamora ${ }^{1} \&$ Doni Andriyan Zunaiedy ${ }^{2}$
}

\begin{abstract}
Combinatorics is a branch of mathematics that is very important, but this topic has not received serious attention in educational research compared to other branches of mathematics such as geometry, calculus and algebra in Indonesia. Meanwhile, in secondary and undergraduate education, existing research reports that students' combinatorial thinking ability tend to be low. Efforts to improve students' combinatorial thinking ability in one of the Vocational Schools in Medan, Indonesia, are carried out through the development of the Numbered Heads Together (NHT). NHT is one cooperative learning structure. The result showed that NHT learning improved students' combinatorial thinking ability.

Keywords: combinatorics, combinatorial thinking ability, numbered heads together
\end{abstract}

\section{INTRODUCTION}

At present, trends in mathematics education, mathematics does not only discuss concepts and numbers, but also takes part in everyday life and becomes a tools of solving problems in daily life. Even though the implementation of combinatorics in real life is very broad, combinatorics that have long been known and studied in school are part of mathematics that are very little discussed, (Syahputra, 2016).

As a branch of mathematics, combinatoric studies discrete objects that can be enumerated. According to Bernoulli, combinatorics was the art of enumerating all possible ways from a number of certain objects that are arranged and placed back with certain pattern (Batanero, et al., 1997). The objects studied by combinatorics emphasize objects that are discrete numbers with their settings and repositions. Around the 16th century, people already knew combinatorics, especially in the application of game theory. In the 17th century people associated combinatorics with Pascal triangles. Bernoulli and Leibniz developed further combinatorics in statistics. Combinatorics is closely related to other topics in mathematics, such as number theory, probability, and inferential statistics (Batanero, et al., 1997; English, 2005; Usry, et al., 2016). Along with the development of technology, the application of combinatorics is increasingly widespread as in the fields of physics, chemistry, biology, communication, computation, and optimization problems (Batanero, et al., 1997; English, 2005; Lockwood, et al. 2015; Syahputra, 2016; Usry, et al., 2016).

However, combinatorics is rated as a difficult topic in mathematics. It is hard to learn and master by students (Melusova and Vidermanova, 2015; Syahputra, 2016) and a lot of evidence shows that students have difficulty in solving enumeration problems (Lockwood, 2015). Usry, et al. (2016) stated

\footnotetext{
${ }^{1}$ Corresponding Author: Rustam E. Simamora

Universitas Borneo Tarakan, Tarakan, Kalimantan Utara, Indonesia

E-mail:erustam@borneo.ac.id
}

${ }^{2}$ Co-Author: Doni Andriyan Zunaiedy

Universitas Islam Negeri, Medan, Sumatera Utara, Indonesia that both of student in secondary school and higher education, students' achievement were weak in this topic. Studies have found that many students from various education level have difficulty to solve problems involving enumeration.

The research conducted by Syahputra (2016) in Indonesia, on 36 high school students and 67 students, showed that the first-year combinatorial thinking ability of mathematics education students were very bad. Students are given five combinatorial problems, then the results are $35 \%$ correct for problem number one, $10.68 \%$ correct for problem number two, there is nothing right for problem number three, $1.9 \%$ correct for problem number four, and only $0.97 \%$ correct for problem number five.

Batanero, et al. (1997), found five types of errors when student facing combinatorial problems: 1 . Interpretation of the wrong question. 2. Incorrect identification of the types of objects used both identical and different, especially letters, numbers, and inanimate objects. 3. Arithmetic operations that are wrongly used in finding solutions. 4. Use of the wrong formula and 5. Incorrect or meaningless answers given. Meanwhile, the results of the Syahputra (2016) study concluded that the low combinatorial thinking ability because students failed to understand the given problems. Students did not understand how to use enumeration process in the calculation. Students obsessed with the fastest formula to solve the problem without considering how the mathematical model of that combinatorial problems.

When conducting a preliminary study at SMK PAB 1 Helvetia (Vocational School), Medan, Indonesia, found a similar problem as described above. The researchers found that the combinatorial thinking ability at the school were low. The researcher gave a question about the rules of enumeration and then continued with an interview about students' views on combinatorial problems. The low ability of students to solve combinatorial problems was effected by learning received by students. Students too often learned in class using expository learning methods. Efforts to improve combinatorial thinking ability using ordinary 
learning model have proven to be less effective. Therefore, another more appropriate learning model is needed. Ordinary learning models will only make students bored, not challenged, passive, or easy to give up. One alternative to solve the above problems is using cooperative learning model. Research related to combinatorial thinking ability has not been widely investigated by researchers. The reason, and the description above encourages researchers to carry out development research in an effort to improve combinatorial thinking ability in SMK PAB 1 Helvetia.

\section{Combinatorics in the Secondary School Curriculum}

Heitele included combinatorics as one of the ten stochastical fundamental ideas that must exist, explicitly or implicitly, in each teaching situation in a stochastic curriculum (in Batanero, et al., 1997). Meanwhile, Freudenthal said that teaching probability must consider combinatorics as a backbone of the basic probability (English, 2005). Furthermore, English (2005) stated that combinatorics provide a basis for solving meaningful problems in various ways and with various representational tools, including manipulative materials. Combinatorial problems also facilitate the development of enumeration processes, guesses, generalizations, and think systematically.

According to Batanero and Sanchez (2013), in secondary schools, students were expected to determine the probability of an event by establishing a probability distribution for a simple sample space, calculating and interpreting the expected values of random variables in simple cases, and describing the sample space in a compound experiment. They are also expected to learn to identify mutually exclusive and shared events, understand conditional probabilities and independence, and utilize their knowledge of combinations, permutations, and calculation principles to calculate these different probabilities. At the end of secondary school, students must understand how to draw conclusions about the population from random samples; a process that involves understanding how a sample can be distributed.

To fulfill the matters above, there is an urgent need to examine more explanations in combinatoric teaching and learning as an interesting part of the school and university mathematics curriculum (Rezaie and Gooya (2011). In the Indonesian curriculum, in combinatorics topic, student learn permutations and combinations in probability topic. This topic is taught very limited, discussions are only on permutation applications and combination formulas, while teachers are more likely to follow the processes contained in mathematical textbooks, mathematics textbooks generally provide formulas and examples of permutations and combinations. Mathematical textbook that overcome difficulties of students in solving combinatoric problems have not provided (Syahputra, 2016).

\section{Combinatorial Thinking Ability}

The way of thinking in solving combinatorics problems is referred to by Rezaie and Gooya (2011) as combinatorial thinking ability, combinatorial thinking ability are an important part of mathematical thinking abilities. Learning combinatorial concepts requires special ways of thinking. The same was stated by Godino, et al. (2007); combinatorial thinking ability is different from other mathematical abilities because combinatorial thinking ability develop students' knowledge by using an uncomplicated approach, namely by sign or semiotic approach.

Combinatorial thinking ability is a process of thinking both consciously and unconsciously related to the process of examining various information, feeling the symptoms of a pattern, feeling the symptoms of similarities and differences from the object, and trying to connect or associate various patterns. Furthermore, combinatorial thinking ability are the basis for solving problems in other branches of mathematics, such as problems in statistics (Batanero, et al., 1997), or problems related to algebra and arithmetic. Therefore, combinatorial thinking ability is one of the abilities that is very important to be possessed by students before learning several fields of mathematics such as geometry, statistics, algebra and arithmetic.

According to Godino, et al. (2005), there are five indicators that a person has combinatorial thinking ability, namely understanding the problem correctly, changing problems into mathematical symbols, making problem solving strategies, making conclusions, and making explanations of conclusions obtained. Meanwhile, according to Lockwood (2013), related ways of thinking students at a level that facilitates a deeper understanding of how students conceptualize enumeration problems, put forward three aspects of mutual relations, namely: the relationship between formula/ expression, calculation process, and set of results.

The results of Rezaie and Gooya (2011), about the combinatorial thinking ability of undergraduate students at one of the universities in Iran, states that there are four levels in combinatorial thinking ability, namely examining appropriate cases, ensuring and calculating all appropriate cases, making announcements from all cases, and change the problem into combinatorial problems. The four levels are the main key to forming students' combinatorial thinking ability. To improve students' combinatorial thinking ability, English (2005) says it can be done by:

\section{Foster independent thinking}

Students are faced with problems that are still in their cognitive reach and then are given the opportunity to explore combinatorial problem situations without direct instruction. The rich and meaningful context in which this problem can be solved means that student have sufficient resources to overcome problems without assistance. However, the teacher's question right when the child is working on the problem can increase the student's understanding of the combination. The teacher can ask students to explain and justify their solutions so that they can reject some of their original ideas, or to modify, correct, or consolidate their original arguments. 


\section{Encourage flexibility in approaches and representations}

Representational fluency has been shown to be at the heart of an understanding of many of the key constructs in elementary mathematics and science. Combinatorial situations lend students to a variety of solution approaches and representations. When presented with novel combinatorial problems, student will naturally display a number of different solution approaches.

\section{Focus on problem structures}

One of the major goals of mathematics education is that student see the connections and relationships between mathematical ideas and apply this understanding to the solution of new problems. Hal tersebut hanya bisa dimungkinkan ketika siswa dapat mengabstraksikan struktur masalah dengan tepat.

\section{Encourage sharing of solutions}

It is recommended that student share their solutions to combinatorial problems with their peers. Student should describe and explain how they arrived at their solutions and why they consider their solutions to be effective ones. When students share their solutions, they provide us with insights into their combinatorial understanding and also provide important opportunities for their peers to give constructive feedback.

\section{Provide problem-posing opportunities}

The ability to pose problems (in addition to solving them) is becoming increasingly important in today's society. By including problem posing in students' experiences with combinatorics, we can increase their access to the combinatorial concepts and procedures and enhance their understanding of combinatorial problem structures.

\section{Provide novel probability problems}

Novel probability problems that utilise combinatorial ideas provide rich opportunities for student to predict, experiment, and analyse probabilistic situations.

In addition to the above, Lockwood (2015) said to teach students with problem solving techniques by trying one or more simpler versions of the problem as a means of gaining insight into solution techniques that can be applied to the initial problem. The utilization of combinatorial enumeration is very useful in the domain of combinatorial enumeration. The strategy of using small cases is a powerful problem solving resource, and the nature of counting problems makes them particularly appropriate for the strategy of using smaller, similar problems. Meanwhile, Melusova and Vidermanova, (2015), say that among the strategies used to solve new combinatorial problems, the elements of the set of results show the most success.

Rezaie and Gooya (2011) identified four levels of understanding in combinatorial thinking that emphasizes enumeration tasks. These levels are as follows: (1) Investigating "some cases". The student's first attempt to deal with the problem was to find "all cases" using the "multiplication principle"; (2) "How am I sure that I have counted all the cases?". Students take one step further and try to convince themselves that they have indeed "counted all cases". Students review the problem and think about it in a more systematic way; (3) Systematically generating all cases; (4) Changing the problem into another combinatorial problem.

\section{Cooperative Learning Model}

There is an idea that states that when people work together to achieve goals it will be better than when people work individually. The idea is the basic idea of the cooperative learning model. Cooperative learning is developed, researched and found to be effective intructionally in elementary and secondary schools. Cooperative learning refers to a set of instructional methods in which students work in small, mixed ability learning groups. There are evidence that students working together in small cooperative groups can master materials better than can students working on their own (Slavin, 1991).

Meanwhile, according to Taylor (1993), the mechanism underlying high level mental work is a copy of social interaction. Schoenfeld (2013) says that ideas formed by individuals are often built and refined in collaboration with others. This implies that even though cognitive, even high-level work in humans, begins a person's interaction with others. In school, students can learn through interaction with adults and peers who are better able through cooperative learning.

According to Slavin, et al. (1991), cooperative learning can be used as the primary instructional method in reading, writing, and mathematics. If students handle most of the checking and management, teachers are free to teach individuals and small homogeneous groups. Cooperative learning is not only an innovation in itself, but also a catalyst for other needed changes in curriculum and instruction. If educational methods are major effects of changes in student achievement, they must address the many elements of the classroom organization and instruction at the same time. Furthermore, Davidson and O'leary (1991) say that cooperative learning shows the power of divergent thinking and learning.

Cooperative learning motivates students to help each other learn. Students can translate teacher language into a language that their friends understand better when studying together. Students who fail to understand the concept presented by the teacher can benefit when discussing the concept with peers who are struggling with the same question. In cooperative learning, students learn by doing it. Students must arrange their thoughts to explain ideas to teammates, they must be involved in cognitive elaboration which greatly increases their own understanding. Students can give individual attention and assistance to each other. Because they work together, students can do a very good job of knowing whether their peers have ideas or need additional explanations. The positive learning 
environment helps and gives a sense of comfort when learning.

The cooperative learning model gives autonomy to the teacher to interact with students directly or indirectly, so that the teacher can be able to improve students' combinatorial thinking ability through structured tasks. The cooperative learning model also supports students to be able to actively participate in classroom learning. One stucture in cooperative learning that may increase class participation among all students is Numbered Heads Together.

\section{Numbered Heads Together}

The Numbered Heads Together (NHT) learning model was developed by Spencer Kagan around the 1990s. This learning model involves students in reviewing the material covered in a lesson and checking or examining their understanding of the content of the lesson. Indirectly train students to share information, listen carefully and talk calculatingly, so students are more productive in learning (Kagan, 1991). According to Yenni (2016), the use of NHT methods in mathematics learning resulted in students becoming more active in learning activities, increasing creativity and involvement of students in the teaching and learning process. Meanwhile, Kartikasasmi, et al. (2012) stated that the application of the NHT learning model with the SETS approach can develop students' creativity and learning outcomes. Some studies also show that mathematics learning outcomes of students who use the NHT method are better than the mathematics learning outcomes of students who use conventional learning (Haydon, et al., 2010; Yenni, 2016; Wahyuni, et al., 2014).

NHT is a cooperative learning strategy in which teachers (a) assign students to small (4 member), heterogeneous learning groups, (b) ask them to number themselves from 1 to 4 , (c) direct questions to the entire class, and (d) tell students to put their heads together, come up with the best answers they can, and make sure that everyone on the team knows the answers (Brandt, 1991; Kagan, 1991). NHT is designed to develop fundamental thinking skills seperti recalling, applying, deducing, predicting (Kagan, 2003b).

Kagan (1991) said that NHT includes teams, positive interdependence and individual accountability, all of which lead too cooperative interaction among students. Positive interdependence is built into the structure: if any student knows the answer, the ability of each students is increased. Individual accountability is also built in: all the helping is confined to the heads together step; students know that once a number is called, each student is on his or her own. The high achievers share answers because they know their number might not be called, and they want their team to do well. The lower achievers listen carefully because they know their number might be called.

The NHT type of cooperative learning syntax consists of: 1) Preparation; 2) Formation of groups; 3) Each group must have a textbook or guidebook; 4) Discussion of problems; 5) Calling member numbers or giving answers; 6) Give conclusions (Ibrahim and Nur,
2000). In this study, the syntax was further developed in an effort to improve students' combinatorial thinking ability.

\section{Preparation}

The teacher prepares instructional materials which consist of: Lesson Plan (LP), Student's Worksheets (SW), Teacher's Handbook (TH), Student Book (SB), and test instruments to measure students' combinatorial thinking ability (CTAT) compiled based NHT. In this study, LP, SW, SB and TH, must meet valid and practical requirements first based on expert judgment. Before conducting learning using NHT, CTAT has fulfill validity and reliability requirement empirically.

Problems that are used as challenges for students when learning is a combinatorial problem originating from the real life of students. The problem is a problem that reflects: (1) fundamental counting principle and that utilizes tree diagrams, systematic lists, and tables; (2) Combinatorial configuration involving (a) selection, (b) distribution, and (c) partition. It is not difficult to arrange combinatorial problems from real life that are interesting, challenging and meaningful for students because of the broad combinatorial application (English, 2005). Problems that are assigned to students, starting from a simpler problem, then slowly bring students face to face with more complex problems in accordance with Lockwood's idea (2015). So the problem to be solved is bottom-up. The initial problem assigned to students must be resolved by recording every possibility without having to be too difficult; for example, students can solve problems using tree diagrams or schemes, tables or members of a set.

On SW, structured information and questions are provided which act as scaffolding to solve the problem. Scaffolding also facilitates the way students conceptualize in solving combinatorial problems consisting of: the relationship between formula/expression, calculation process, and set of results (Lockwood, 2013). Problems assigned to worksheets are sought to be transformed into other combinatorial problems (Rezaie and Gooya, 2011). Meanwhile, the SB contains combinatorial materials, practice questions and what students can use to learn independently at home.

Problems within SW are also included in the SB, along with alternative answers. But the alternative answers to the SB on the problem are just a short answer to anticipate students just move the alternative answers in SB to SW when students work in groups. Student CTAT is compiled using indicators proposed by Godino, et. al. (2005), namely understanding the problem correctly, changing the problem into mathematical symbols, making problem solving strategies, making conclusions, and making explanations of the conclusions obtained. These indicators are included in structured questions on each problem in the CTAT. This is in accordance with the chosen learning approach, namely students learn by work (Dewey, 1938). 


\section{Group formation and numbering}

In the implementation of learning it is necessary to organize students in the classroom. Teachers must implement learning strategies that allow students to interact with their friends (Simamora, et al., 2019). In this NHT, the teacher divides students into groups, then shares the numbers with each student in the group. Each student will study in his group.

In this study, each group was formed with members of four students. Each group consists of: - one high achiever, two average achievers, and one low achiever. Next, the teacher asks students to number each group member from number 1 to 4 . The students are taught in class, but also for helping their group learn. Often, there is some sort of group goal (Slavin, 1991). In addition, group formation also takes into account ethnicity, gender and the comfort of each student in the group.

\section{Problem posing}

The teacher asks students to work on the SW and open the SB that has been shared with each group. SW was divided into two sets of each group at the previous meeting. Meanwhile, SB was distributed one set to students at the previous meeting. SW is not given to each student to avoid students working individually. Next, each group was asked to discuss the questions on the SW together. In this NHT, students are not taught by direct learning, but by constructing their knowledge through scaffolding (Vygotsky, 1978) given by the teacher and structured questions in the SW and from the teacher, and information from the SB Students are given the opportunity to explore each problem.

\section{Problem solving with team}

In this phase each student thinks together to complete the tasks in the worksheet as well as they can. Students are also asked to describe and ensure that each person in the group knows the answers to the questions that have been compiled in the SW. During group discussions, students are assisted by teachers and peers. The teacher acts as a facilitator. In accordance with Vygotsky's beliefs, students who are taught through problem solving will improve student cognition (Taylor, 1993).

When solving problems or answering structured questions in SW, Siska does the math. Students work like mathematicians propose and solve problems; students experience directly the characteristics of mathematics as a social institution, submission and problem solving (Ernest, 1991). In the discussion of solving students 'problems, students' curiosity is developed through combinatorial problems originating from everyday life, gaining knowledge, increasing problem solving skills, providing good understanding and thinking independently. The teacher does not only train students to solve problems or routine operations (Polya, 1973).

\section{Calling number}

After the specified time, the teacher calls one number and the students from each group with the same number raise their hands. In this study, there were eight groups of students. Providing opportunities for eight students who have the same number to present answers to problems in SW, it will take a lot of time. The eight people were asked to come forward to show their work, then the teacher chose two students; one student who gave a complete and correct answer and one student who gave an interesting answer. The two people were asked one by one to present the answer.

\section{Concluding}

At this stage, the teacher and the students conclude the answers to each question with the structure of the problem. If in a meeting, problems that must be resolved by a group of students are more than one problem, then the Issuance phase, Discuss the problem, Call the member number or give an answer, and Give conclusions, repeated again. At the end of the lesson, before closing the meeting, the teacher gives homework to be done by students in private as an exercise.

\section{METHOD}

This research is development research (design research). This study uses a model of development of Thiagarajan et al. (1974) which is also often referred to as 4-D to develop instructional materials. Development research is carried out to obtain learning tools that are valid, practical, and effective (Nieveen \& Folmer, 2013) and improve students' combinatorial thinking ability.

The research was conducted at SMK PAB 1 Helvetia which is one of the Vocational Schools in Medan, Indonesia. Subjects in this study were class X SMK PAB 1 Helvetia $\left(10^{\text {th }}\right.$ year vocational school) in $2018 / 2019$ academic year, while the objects in this study were learning using the NHT type cooperative learning model. The learning test using NHT was conducted twice, each in class X Multimedia 1 and Class X Multimedia 2, which each class consisted of 32 students. The trial design used in this study was preexperimental approach, namely one-group pretestposttest design (Sugiyono, 2017). The design of this study is presented in Table 1:

Table 1. Nonequivalent Control Group Design

$\begin{array}{cc}\mathrm{E}: & \mathrm{O}_{1} \quad \mathrm{X}\end{array}$

The results of the combinatorial thinking ability test of the experimental group before and after the experiment were tested with differences in the mean calculated by sample related t-test (Sugiyono, 2017) or Paired-Samples T Test. In this case the researcher used a two-tails test at the $95 \%$ confidence level. Meanwhile, the submission of descriptive hypotheses in the analysis of each trial is:

$H_{0}$ : "There is no difference in combinatorial thinking ability of students before and after learning" 
$H_{1}$ : "There are differences in combinatorial thinking ability of students before and after learning"

As explained above, the instrument used to measure students combinatorial ability is Combinatorial Thinking Ability Test (CTAT) in the form of an essay test which is divided into two groups, namely: pretest and posttest, each of which consists of five questions. The test has been tested for validity and reliability before use. Before the CTAT results data were analyzed using the t-test, first the validity and homogeneity of the pretest and posttest data were tested. The normality of the data was tested using Kolmogorov-Smirnov, while checking the variance of the data was tested using Levene. The test is carried out using SPSS 20 software.

\section{RESULT AND DISCUSSIONS}

The results of testing the normality of data using Kolmogorov-Smirnov using the results that the pretest and posttest data, both in trial 1 and Trial 2 showed that the data were normal distribution. Checking the homogeneity of variance pretest-posttest, both in Test 1 and in Trial 2 shows that the data is homogeneous or comes from the same population. In trial 1, it was found that the average result of the student's pretest was 29; posttest 68.25. Meanwhile, in Trial 2, it was found that the average result of the student's pretest was 31.75; posttest 76.25. Both in Test 1, and Trial 2, the results of statistical analysis using Paired-Samples T Test showed that $H_{0}$ was rejected and $H_{1}$ was accepted. So, it was concluded that there were differences in combinatorial thinking ability of students before and after learning. Because the average posttest results of students are better than the pretest, it can be concluded that NHT can improve combinatorial thinking ability.

In Trial 1, even though students' combinatorial thinking ability had improved, the results of the development of the NHT learning model did not meet the effective criteria, because the average combinatorial thinking ability of students had not reached the minimum completeness criteria. Meanwhile, in Trial 2, the results of developing the NHT learning model have reached effective criteria. So, the results of the development of the NHT model have met the criteria valid, practical and effective in Trial 2.

The cause analysis of the ineffectiveness in Trial 1 was carried out qualitatively. At the time of Trial 1 it was found that there were several groups whose members did not feel comfortable with each other. In addition, while teaching students using instructional materials (SW and SB), there were still problems that were too difficult for students to understand and then scaffolding on tasks was still not sufficiently helpful for students. To overcome this, in Trial 2, each group member was certain to feel comfortable with each other first. Instructional materials that used by students were revised; each problem used simple language and could guide students to understand the subject matter (Yerizon, et. al., 2018). In addition, scaffolding on instructional materials was equipped with more visual. Test results in Trial 2 showed that these efforts prove effective, the more students had good combinatorial thinking ability, the more the minimum completeness criteria were achieved.

The increase in students' combinatorial thinking ability is inseparable from the integration of Vygotsky's theory into the NHT learning model. Vygotsky (1978) states that the experience of students when solving problems with their study groups with a socio-cultural approach will improve mental function higher. In cooperative learning, students learn by doing in accordance with the ideas of Dewey (1938) and Slavin (1991). In NHT learning, students discuss with their peers. Students explain one another to learn. When students organize their thoughts to explain their ideas and engage in cognitive skills and then increase their combinatorial thinking ability.

Dewey (1986) said: "The most important attitude that is formed is desire to go on learning". With this NHT learning, students' desire to learn or want to know increases. This can be noted from the high involvement. This is in accordance with the results of Yenni's research (2016) which states that the application of NHT in mathematics learning results in students becoming more active in learning activities, increasing creativity and involvement of students in the teaching and learning process.

The increase in combinatorial thinking ability of students in this study is also inseparable from feeling comfortable and feeling happy when learning using NHT. Discussion with problem solving, as Schoenfeld (2013) said, provided a way into the joys of doing mathematics and the pleasures of discovery. As previously explained, the problems assigned to students in NHT learning are combinatorial problems that are made interesting and meaningful, while at the same time, challenging for students and making students are able to work effectively (English, 2005).

The idea of English (2005) in enhancing students' combinatorial thinking ability, fostering independent thinking of students, encouraging flexibility in learning and representation, focusing on problem structures, encouraging sharing of solutions, and providing novel probability problems covered by NHT learning. This design affect the effectiveness of the NHT in improving combinatorial thinking ability of SMK PAB 1 Helvetia students.

The increase in combinatorial thinking ability of students in this study is in accordance with what was said by Slavin, R.E. (1985) that most studies show that high, average, and low achievers are equally from the cooperative experience; a few have shown greater gains for low achievers; and others have shown the greatest gains for high achievers. Furthermore Kartikasasmi, et al. (2012) stated the same, that the application of the NHT learning model with the SETS approach can develop students' creativity and learning outcomes. 


\section{CONCLUSION}

NHT proposed by Spencer Kagan (1991), in this study, was further developed based on ideas from various experts. The development of the NHT model is realized by the compilation of instructional materials and operationalizing these materials when testing. From the discussion above, it can be concluded that the combinatoric thinking ability of students has increased after learning using NHT learning in class X of SMK PAB 1 Helvetia. The results of this study were obtained through pre-experimental research design with one-group pretest-posttest design. Therefore, further research is still needed by using control groups to get better conclusions or more convincing ones. In addition, it is also recommended, if the students learn with cooperative learning, it is certain that group members feel comfortable with each other; instructional materials that used by students using simple language and facilitating students with scaffolding with a visual matter so that materials can guide students to learn by solving problems.

\section{ACKNOWLEDGMENTS}

We thank Edi Syahputra and Asmin Panjaitan for helping in designing learning model and research process.

\section{REFERENCES}

Batanero, C., Godino, J.D., \& Navarro-Pelayo, V. (1997). Combinatorial Reasoning and its Assessment. In I. Gal, \& J. B. Garfield (Eds). The Assesment Challenge in Statistics Education (pp. 239 - 252). Amsterdam: International Statistical Institute \& I.O.S. Press.

Batanero, C., \& Sanchez, E. (2013). What is The Nature of High School Students' Conceptions and Misconceptions About Probability?. In G. A. Jones (Ed.). Exploring Probability in School: Challenges for Teaching and Learning (pp. 260 - 289). Netherland: Kluwer Academic Publishers.

Brandt, R.S. (1991). On CooperativeLearning: A Conversationwith Spencer Kagan. In R.S. Brandt (Ed.). Cooperative Learning and the Collaborative School:Readings from "Educational Leadership" (pp. 29 - 32). Alexandria: Association for Supervision and Curriculum Development.

Davidson, N., \& O'leary, P.W. (1991). How Cooperative Learning Can Enhance Mastery Teaching Neil. In R.S. Brandt (Ed.). Cooperative Learning and the Collaborative School:Readings from "Educational Leadership" (pp. 30 - 33). Alexandria: Association for Supervision and Curriculum Development.

Dewey, J. (1938). Experience \& Education. New York, NY: Kappa Delta Pi.

Dewey, J. (1986). Experience and Education. The Educational Forum, 50(3), $241-252$, https://doi.org/10.1080/00131728609335764

Ernest, P. (1991). The Philosophy of Mathematics Education. London: Routledge Falmer.

English, L. D. (2005). Combinatorics and The Development of Children's Combinatorial
Reasoning. In Graham A. Jones (Ed.). Exploring Probability In School: Challenges for teaching and learning (pp. 121 - 141). Netherland: Kluwer Academic Publishers. doi:10.1007/0-387-245308

Godino, J.D., Batanero, C., \& Font, V. (2007). The Onto-Semiotic Approach to Research in Mathematics Education. The International Journal on Mathematics Education,39(1), 127 - 135.

Godino, J.D., Batanero, C., \& Roa, R. (2005). An Onto-Semiotic Analysis of Combinatorial Problems and The Solving Processes by University Students. Educational Studies in Mathematics, 60, 3 - 36. https://doi.org/10.1007/s10649-005-5893-3

Haydon, T., Maheady, L., \& Hunter, W. (2010). Effects of Numbered Heads Together on the Daily Quiz Scores and On-Task Behavior of Students with Disabilities. Journal of Behavioral Education,19(3), 222 - 238. doi:10.1007/s10864010-9108-3

Ibrahim, M., \& Nur, M. (2000). Pembelajaran Kooperatif. Surabaya: University Press.

Kagan, S. (1991). The Structural Approach to Cooperative Learning. In R.S. Brandt (Ed.). Cooperative Learning and the Collaborative School:Readings from "Educational Leadership" (pp. 33 - 36). Alexandria: Association for Supervision and Curriculum Development.

Kagan, D. M. (1992a). Professional Growth among Pre-service and Beginning Teachers. Review of Educational Research, 62(2), 129 - 169. https://doi.org/10.3102/00346543062002129

Kagan, S. 1992b. Cooperative Learning. San Juan Capistrano: Kagan Cooperative Learning.

Kagan, S. (2003a). A Brief History of Kagan Structures. Retrieved from https://www.kaganonline.com/free_articles/dr_spen cer_kagan/256/A-Brief-History-of-KaganStructures

Kagan, S. (2003b). Kagan Structures for Thinking Skills. Retrieved from https://www.kaganonline.com/free_articles/dr_spen cer_kagan/280/Kagan-Structures-for-ThinkingSkills

Kartikasasmi, H., Khanafiyah, S., \& Sutikno. (2012). Penerapan Model Pembelajaran NHT dengan Pendekatan Sets Pada Materi Cahaya untuk Mengembangkan Kreativitas Siswa. Lembaran Ilmu Kependidikan, 41(2),122 - 30.

Lockwood, E. (2013). A Model of Students' Combinatorial thinking: The Role of Sets of Outcomes. Journal of Mathematical Behavior, 32, 251 265. https://doi.org/10.1016/j.jmathb.2013.02.008

Lockwood, E. (2015). The Strategy of Solving Smaller, Similar Problems in the Context of Combinatorial Enumeration. International Journal of Research in Undergraduate Mathematics Education, 1, 339 362. https://doi.org/10.1007/s40753-015-0016-8

Lockwood, E., Swinyard, C. A., \& Caughman, J. S. (2015). Patterns, Sets of Outcomes, and Combinatorial Justification: Two Students' 
Reinvention of Counting Formulas. International

Journal of Research in Undergraduate Mathematics Education, $1,27-62$. https://doi.org/10.1007/s40753-015-0001-2

Melusova, J., \& Vidermanova, K. (2015). Uppersecondary Students' Strategies for Solving Combinatorial Problems. Procedia - Social and Behavioral Sciences, 197(2015),1703 - 1709. https://doi.org/10.1016/j.sbspro.2015.07.223

Nieveen, N., \& Folmer, E. (2013). Formative Evaluation in Educational Design Research. In T. Plomp, \& N. Nieveen. Educational Design Research. Netherland: SLO.

Polya, G. (1973). How To Solve It (2nd ed). Princeton: Princeton University Press.

Rezaie, M., \& Gooya, Z. (2011). What do I mean by Combinatorial Thinking?. Procedia Social and Behavioral Sciences, 11(2011), 122 - 126. doi:10.1016/j.sbspro.2011.01.046

Schoenfeld, A. H. (2013). Reflections on Problem Solving Theory and Practice. The Mathematics Enthusiast, 10(1,2), 9-32.

Simamora, R.E., Saragih, S., \& Hasratuddin. (2019). Improving Students' Mathematical Problem Solving Ability and Self-Efficacy through Guided Discovery Learning in Local Culture Context. International Electronic Journal of Mathematics Education,14(1), $61 \quad-\quad 72$. Retrived from https://doi.org/10.12973/iejme/3966

Slavin, R.E. (1985). An Introduction to Cooperative Learning Research. In R.E. Slavin, S. Sharan, S. Kagan, R.H. Lazarowitz, C. Webb, \& R. Schmuck (Eds). Learning to Cooperate, Cooperating to Learn (pp. 5 - 16). New York: Plenum Press. doi:10.1007/978-1-4899-3650-9

Slavin, R.E. (1991). Cooperative Learning and the Cooperative School. In R.S. Brandt (Ed.). Cooperative Learning and the Collaborative School: Readings from "Educational Leadership" (pp. 2 -8). Alexandria: Association for Supervision and Curriculum Development.

Slavin, R.E., Madden, N.A., \& Stevens, R.J. (1991). Cooperative Learning Models for the 3 R's. In R.S. Brandt (Ed.). Cooperative Learning and the Collaborative School:Readings from "Educational Leadership" (pp. 18 -20). Alexandria: Association for Supervision and Curriculum Development.
Slavin, R.E. (1995). Cooperative Learning: Theory, Research and Practice (2nd ed.). Boston: Allyn and Bacon.

Sugiyono. (2017). Metode Penelitian Kuantitatif, Kualitatif dan $R \& D$. Bandung: Alfabeta.

Syahputra, E. (2016). Combinatorial Thinking (Analysis Of Student Difficulties And Alternative Solution). The Third Annual International Seminar on Trends in Science and Science Education 7th8th October 2016, 1 - 13.

Taylor, L. (1993). Vygotskyan Scientific Concepts: Implications for Mathematics Education. Focus on Learning Problems in Mathematics, 15, 2 - 3.

Thiagarajan, S., Semmel, D. S. \& Semmel, M. I. (1974). Instructional Development for Training Teachers of Exceptional Children. A Sourcebook Indiana: Indiana University

Usry, R., Rosli, R., \& Maat, S. M. (2016). An Error Analysis of Matriculation Students' Permutations and Combinations. Indian Journal of Science and Technology, $\quad 9(4), \quad 6 \quad 1 \quad-6$. http://dx.doi.org/10.17485/ijst\%2F2016\%2Fv9i4\% 2F81793

Vygotsky, L. S. (1978). Mind in Society: The Development of the Higher Psychological Processes. Cambridge, MA: The Harvard University Press. (Originally published 1930, New York: Oxford University Press).

Wahyuni, E.T., Budiyono, \& Sujadi, I. (2014). Eksperimentasi model pembelajaran kooperatif tipe Numbered Heads Together (NHT) dan Think Pair Share (TPS) pada Materi Pokok Trigonometri Ditinjau dari Kecerdasan Emosional Siswa SMK di Kota Madiun Tahun Pelajaran 2013/2014. Jurnal Elektronik Pembelajaran Matematika, 2(6), 558 567.

Yenni, R.K. (2016). Penggunaan Metode Numbered Head Together (NHT) dalam Pembelajaran Matematika. Nabla Dewantara: Jurnal Pendidikan Matematik, 1(2), 33 - 42.

Yerizon, Putra, A. A., \& Subhan, M. (2018). Mathematics Learning Instructional Development based on Discovery Learning for Students with Intrapersonal and Interpersonal Intelligence (Preliminary Research Stage). International Electronic Journal of Mathematics Education, 13(3), 97-101. https://doi.org/10.12973/iejme/2701 